\title{
En verden i stadig forandring. Norsk barnelitteratur i det post-sekulære samfunn
}

\author{
Åse Marie Ommundsens artikel diskuterar förnuft och tro utifrån \\ filosofen Jürgen Habermas och teologen och påven Joseph Ratzingers \\ teorier. Två norska, samtida barnböcker 12 ting som må gjerast \\ rett før verda går under och Frosken illustrerar båda likartade \\ existentiella frågeställningar, men svaren de föreslår skiljer sig åt.
}

Globaliseringen tvinger frem det religiøse. I et samfunn mange trodde var "ferdig" sekularisert, er det oppstått nye, store problemer knyttet til religion. Dette oppleves som dramatisk i forhold til den kulturutviklingen vi har hatt, og som blodig alvor for de ikkesekulariserte. Den siste tidens debatt har vist at man er nødt til å forholde seg til kulturforskjellene. Dette avspeiler dialogen mellom "den religiøst umusikalske" filosofen Jürgen Habermas og teologen, og nå pave, Joseph Ratzinger (Habermas og Ratzinger 2006). De to tenkerne enes om at de siste års hendelser har vist at vi lever i en ny situasjon, der religion spiller en stadig viktigere rolle. Mye er skjedd siden man i vesten i 1970-årene koblet religionen ut av den offentlige samtalen. Den sekulære tidsalder er over, og erstattet med "det postsekulære samfunn". I det postsekulære samfunn må, i følge Habermas, "moderniseringen av den offentlige bevissthet" ta opp religiøse og verdslige mentaliteter og endre dem refleksivt: "Begge sider vil $\mathrm{nu}$, forudsat at de sammen forstår samfundets sekularisering som en komplementær læreproces, også gensidigt kunne tage hinandens bidrag $\mathrm{i}$ offentligheden vedrørende kontroversielle emner alvorlig ud fra kognitive grunde." (Habermas og Ratzinger 2006, 38) Filosofien og kristendommen har en felles historie fra antikken og frem til i dag. Ratzinger understreker at på samme måte som religionen har sine grenser, har også fornuften sine. Som eksempler viser han til atombomben og produksjon av mennesker, begge deler er hva han kaller fornuftens verk. Han etterlyser en polyfon korrelasjon mellom fornuft og tro, fornuft og religion, "så det der holder verden sammen, 
igjen kan blive en virksom kraft i menneskeheden." ${ }^{1}$ (Habermas og Ratzinger 2006, 62)

Idéen om det postsekulære samfunn gjenspeiles i litteraturens gjenreising av religiøse problemstillinger. Mens religiøse barneblader dominerte i den norske barnelitteraturens første fase, forsvant det religiøse gradvis fra barnelitteraturen utover 1900-tallet, og da særlig på 1970-tallet. I flere år var det tabu å skrive om religiøse problemstillinger. Samtidig, på siden, eksisterte det et lite, marginalisert kretsløp av religiøse forlag som ga ut barnelitteratur som skulle forkynne kristen tro. I motsetning til de kristne barnebladene på 1800-tallet, nådde imidlertid ikke disse bøkene ut til et særlig stort publikum. Men også her viskes grensene ut, og i begynnelsen av det nye årtusenet har religiøse problemstillinger funnet veien tilbake til litteraturen. De religiøse problemstillingene ser ut til å bevege seg fra periferien og inn mot sentrum, i tråd med Maria Nikolajevas (1996) modell. Inspirert av Yuri Lotmans semiotiske tilnærming, søker modellen å forklare barnelitteraturens utvikling, der sentrale fenomen blir erstattet av grenselinjefenomener: "Since in any semiosphere it is the borderline that is active, while its centre is passive, the borderline texts move successively towards the centre." (Nikolajeva 1996, 62)

I nyere norsk skjønnlitteratur er kretsing rundt grunnleggende eksistensielle spørsmål en gjennomgående tematikk. Det at et flertall av forfatterne bruker koden (wide distribution), og at koden brukes oftere enn andre koder (great frequency) er i følge Nikolajeva to av de viktigste kriteriene som kan avgjøre om et fenomen - i dette tilfellet eksistensielle spørsmål - er i ferd med å bli den nye, sentrale koden som plasserer seg i sentrum. Det tredje kriteriet er høy status, og her er bildet mer tvetydig. På den ene siden, er kretsingen rundt fundamentale eksistensielle spørsmål et typisk trekk ved store deler av all-alder-litteraturen, som utvilsomt har høy status innen barnelitteraturen. På den andre siden har vi nedvurderingen som ligger i kritikeren Eivind Tjønnelands påstand om at norske 1990-tallsforfattere er "på lemenmarsj mot Gud" (Dagbladet 2000). Litteraturviteren fyrer løs mot forfattere som Dag Solstad, Jon Fosse, Jan Kjærstad og Tore Renberg. Tjønneland kritiserer voksenlitteraturen, men det ser ut til at den økende tendensen til å dreie litteraturen omkring eksistensiell problematikk er ledet an av førende forfattere av norsk barne- og ungdomslitteratur. Prisbelønte forfattere som Jostein Gaarder, Harald Rosenløw Eeg og Bjørn Sortland skriver romaner som dreier seg omkring eksistensielle spørsmål og antydninger til svar. Spesielt Jostein Gaarders romaner har hatt stor betydning for den filosoferende trenden vi kan se i dagens litteratur. Sofies verden (1991) 
er oversatt til 54 språk og solgt i mer enn 35 millioner eksemplarer (Filmweb 2007). Den er en av verdens mestselgende bøker, og var verdens mest solgte roman i 1995. Gaarder har dermed hatt stor betydning også utenfor Norges grenser, kanskje mer enn noen annen norsk forfatter.

Det var Gaarder som satte de store gåtene på dagsorden. Med sin kombinasjon av filosofisk fornuft og religiøs undring innledet han et paradigmeskifte i litteraturen: en dreining fra det sekulære til det postsekulære. Trenden viser seg både i form av skjønnlitteratur og filosofibøker for barn. Gaarder var en toneangivende forfatter som åpnet opp for spørsmål det til tider har vært tabu å snakke om. Samtidig som den nye læreplanen, Kunnskapsløftet (2006), innfører filosofi i grunnskolen, kommer det ut flere filosofibøker for barn. Både Vera Michaelsens filosofibok På månen spiser de kameler (2006), og de oversatte Tenkofilbøkene Hva tenker du om livet?, Hva tenker du om godt og vondt? og Hva tenker du om følelser? åpner for filosofisk diskusjon ved å stille spørsmål, der hvert enkelt spørsmål gis flere ulike svar, i en likeverdig flerstemmighet. ${ }^{2}$ Men også i skjønnlitteraturen kan vi finne både eksistensielle spørsmål og svar.

Som Peter Hollindale og John Stephens påpeker, inneholder alle tekster ideologi, enten åpent eller skjult, eksplisitt uttalt, passivt implisitt eller innbakt i språket. ${ }^{3}$ Stephens understreker at "Ideologies, of course, are not necessarily undesirable, and in the sense of a system of beliefs by which we make sense of the world, social life would be impossible without them." (Stephens 1992, 8) Selv om tekster uten ideologi ikke finnes, kan leseren likevel oppleve en tekst som ideologi-fri: "/---/ if you read a book and discover that it is utterly free of ideological presuppositions, what that really means is that you have just read a book which precisely reflects those societal presuppositions which you yourself have learned to subscribe to, and which are therefore invisible." (Stephens 1992, 50) Interessant i denne sammenhengen er det at to av Englands mest prisbelønte og toneangivende forfattere ser ut til å ha valgt to helt forskjellige ideologiske posisjoner i sine prisbelønte verk. Forfatteren og teoretikeren Aidan Chambers har stilt spørsmål ved hvorvidt åndelighet kan sees som det siste gjenværende tabu i engelsk ungdomslitteratur (Chambers 2006). Selv skriver han romaner som handler om tro og tvil, men uten å være forkynnende. På den andre siden blir forfatteren Philip Pullman beskyldt for å drive med forkynnelse av ateistisk eller antikristen tro ${ }^{4}$ (Padley \& Padley 2006; Ryan \& Ryan 2003; Huovinen 2006).

Norsk barne-og ungdomslitteratur lever selvfølgelig ikke i et va- 
kum i vår globaliserte verden. Likevel er norsk barnelitteratur i en spesiell situasjon i og med at den skrives på et språk som bare noen få millioner mennesker bruker. Den unike norske innkjøpsordningen, som skal sikre at alle barnebøker av akseptabel kvalitet kjøpes inn i 1550 eksemplarer til bibliotekene (149 i 2005), samt bildebokstøtten, muliggjør både utfordrende og eksperimentelle utgivelser som ikke nødvendigvis selger særlig godt (Årboka 2007). Innkjøpsordningen sikrer forfatterne inntekt uavhengig av om bøkene deres selger eller leses. Kanskje er dette en av årsakene til at norske bildebøker sies å være mindre tradisjonelle og idylliserende enn svenske bildebøker? (Se f.eks Rhedin 2004)

Litteraturen gjenspeiler det samfunnet den skrives i. Den senmoderne, norske virkeligheten åpner opp for både eksistensiell undring og ulike forsøk på svar. Hva innebærer det å leve i et postsekulært samfunn? Gjennom to eksempler vil jeg forsøke å vise hvordan det postsekulære kommer til uttrykk i den norske barnelitteraturen. Hvilke eksistensielle spørsmål og svar kan vi finne i nyere norsk skjønnlitteratur for barn og unge?

\section{En verden i stadig forandring}

Fins Gud? spør 13 år gamle Therese i Bjørn Sortlands 12 ting som må gjerast rett før verda går under (2001). Bjørn Sortland skildrer en familie som går i oppløsning sett fra Thereses ståsted. Humor blir brukt som en av flere overlevelsesstrategier når Thereses verden ser ut til å gå under. En av globaliseringens samfunnsmessige konsekvenser er at vi alle er nødt til å leve et liv med valg, hevder sosiologen Zygmunt Bauman i Globaliseringen og dens menneskelige konsekvenser (Bauman 1998, 100). Vi er alle i bevegelse enten vi vil det eller ei, ettersom ubevegelighet ikke er noen realistisk valgmulighet $i$ en verden i stadig forandring (Bauman 1998, 22). Bauman hevder altså at vi er dømt til å leve et liv med valg, men ikke alle har muligheten til å bli velgere (Bauman 1998, 100). Både geografi, økonomi og sosial plassering er avgjørende, samt ikke minst evnen til å stille de rette spørsmålene: " $\AA$ stille de rette spørsmålene utgjør tross alt forskjellen mellom skjebne og bestemmelse, mellom å streife omkring og å reise mot et mål." (Bauman 1998, 25) Therese har muligheten til å bli velger og tilgang til "global mobilitet" (Bauman 1998, 102). Det viser seg at hun også har evnen til å muliggjøre seg den globaliserte verdens muligheter. Hun velger å stille "de rette spørsmålene" og reise mot et mål, og gir seg ikke før hun finner svar på sine eksistensielle spørsmål, og får gjort de 12 tingene som må gjøres før verden går under. Romanen, 
som vant Skandinavisk romankonkurranse 2001 og ble nominert til Brageprisen samme år, er et eksempel på en bok skrevet for barn som blir plassert både i bokhandelens hylle for skjønnlitteratur for voksne og i hyllene for barnelitteratur. Tematikken dreier seg om eksistensielle spørsmål, og humor brukes som virkemiddel. Det er en lys bok om vanskelige ting.

Therese lever i en liten bygd på vestlandet med mor og far - trodde hun - og sin voksne, psykisk utviklingshemmede søster Randi-Irene. I kapittelet "Pappa som berre vart så utruleg flink til å laga salat" får vi hennes forklaring på skilsmissen mellom foreldrene:

- Hva var det som skjedde da foreldrene dine bestemte at de skulle skille seg? spør Jan plutselig.

- Pappa blei så veldig flink å laga salat, seier eg.

- Det var i alle fall det ei dame på jobben hans sa ein gong eg stakk innom ein fredag for å ta nokre fargekopiar på kontoret hans: - Du er heldig som har ein pappa som er veldig flink til å laga salat, veit du det? sa ho og blunka. Det var nytt for meg, og eg forstod at noko hadde skjedd. Pappa har aldri laga noko anna enn speilegg. (Sortland 2001, 96)

Therese opplever skilsmissen mellom foreldrene som traumatisk. Hun ber til Gud "Om at mamma og pappa ikkje må gå frå kvarandre likevel, og om at han, uansett, må visa meg at han finst, og om at han må sjå meg fordi eg kjenner meg så åleine at eg berre vil dø." (Sortland 2001, 23) Therese kan sies å lide av en akutt eksistensiell usikkerhet, angst og frykt. Men selv om det føles som om verden holder på å gå under, får hun ikke panikk. Hun velger seg Jan, som hun er nysgjerrig på, og som hun opplever en gryende forelskelse i, til å diskutere eksistensielle spørsmål med. Ikke skilsmissen, det blir for vanskelig, men reserve-temaet "Verdas undergang", ettersom "Det skulle passa godt no, og ikkje vera så vanskeleg." (Sortland 2001, 31) Jan er "kristen-kristen" og har nettopp flyttet til bygda fra Manglerud i Oslo på grunn av farens prestestilling. "Eg kan ikkje for det, men eg tenkjer at kanskje, kanskje er Jan ein skatt som ingen enno har oppdaga, og eg vil i så fall vera den første som grev han opp." (Sortland 2001, 29)

Den eksistensielle angsten Therese føler, har sammenheng med globaliseringens utilsiktede konsekvenser. I en verden der de fleste mennesker mangler innflytelse og kontroll, kan fremtiden føles mer som en trussel enn som et lovet land: "Budskapet er enkelt: Enhver er potensielt overflødig eller kan erstattes, og derfor er enhver sårbar; og enhver sosial stilling /---/ er usikker i det lange løp." (Bauman 1998, 11) En kan 
erstattes både som arbeidstager, som ektefelle, og til og med som barn. Denne utrygge tilstanden gjør all fremtid usikker: "det finnes ingen solid stengrunn under som man kan hvile bena på" (Bourdieu 1998, her fra Bauman 1998, 11). Bauman understreker hvordan det "å være i bevegelse" har en radikalt annerledes og motsatt betydning for dem som er på toppen og dem som er på bunnen av hierarkiet: "hovedtyngden av befolkningen - den 'nye middelklassen' - svinger mellom de to ytterpunktene, bærer tyngden av motsetningsforholdet mellom dem og lider som følge av det akutt eksistensiell usikkerhet, angst og frykt." (Bauman 1998, 24; min utheving) Nettopp en slik akutt eksistensiell angst er det skilsmissen utløser i Therese.

Frykten for verdens undergang blir et bilde på katastrofen som har inntruffet $i$ Thereses eget liv: Hennes verden er gått under. Denne undergangen blir en parallell til den undergangen hun etterhvert skal bli mer og mer opptatt av: Frykten for at jorda skal gå under. I kapittelet som heter " $\AA$ snakka med ein kristen gut" tar Therese endelig mot til seg og snakker til Jan for første gang. Hun bruker frykten for at jorda skal gå under som påskudd for å snakke med ham, og hevder at hun er "verkeleg verkeleg redd":

- All denne oppvarminga av drivhuseffekten. Dyra som dør. Alle sjukdommane i Afrika som kjem frå apekattane, bakteriane som plutselig tåler alt.

- De resistente? spør Jan.

- Ja, dei òg. Og krigane. Alle jordskjelva og dei heimlause. Ungane i Russland og Romania som frys og bur i kloakksystem under gata og bruker narkotika før dei er fem. Og all sprayinga av gift på frukt, til og med i Hardanger, seier eg og nikkar til eplet hans. Han stopper å eta. (Sortland 2001, 33-34)

Slik starter vennskapet deres med en felles angst for en usikker fremtid. De finner hverandre i sin søken etter svar. Sammen lager de en liste over tolv ting som må gjøres rett før verden går under. Listen gjenspeiler de eksistensielle spørsmålene: Den handler om relasjoner både til Gud og mennesker en bryr seg om, om være ærlig og å prioritere riktig i forhold til hva en skal bruke livet til.

Listen fører dem til Roma, som er det 3. punktet på lista: "Reisa til draumeplassen sin." De to trettenåringene reiser uten at foreldrene vet om det, og tar med Randi-Irene som "inngangsbillett" ettersom hun er myndig, lokket med ved hjelp av mokkabønner og nytt termometer til akvariet. I løpet av helgen i Roma får Therese og Jan krysset ut punktene på lista, ett etter ett. Som en understreking av 
globalitetens hastighet strekker romanens handlingsforløp seg over kun elleve dager: "Ting går vanvittig fort. At alt kan forandra seg frå eit øyeblikk til eit anna /---/" (Sortland 2001, 6).

Romanen starter med slutten. Slutten avsløres allerede i første setning, under kapitteloverskriften "Det hadde eg ikkje trudd": "Berre ti dagar etter at eg spurte Gud om han såg meg, fekk eg svar." (Sortland 2001, 5) Romanens høydepunkt er nettopp når sirkelen sluttes og Gud svarer på det 11. punktet på lista: "Be Gud om at han på ein eller annan måte må fortelje meg at han finst." Gudsbeviset i 12 ting som må gjerast rett før verda går under, kommer i form av "skrifta i sand", et lynnedslag på stranden som forsteines til et lite glasspyd - en allusjon til Guds åpenbaring for Moses. (2. Mos. 19.18, 2. Mos. 24.17, 2. Mos. 31.18)

\section{En forundret frosk i forandring}

Gud er en illusjon, eller Gud er død, er budskapet i bildeboka Frosken (2003) av Hans Sande og Gry Moursund. (Ill. 1) Alle tekster er multimodale, men i tolkningen av bildeboka er samspillet mellom de ulike modalitetene særlig avgjørende. Bildeboka inneholder flere ulike modi av like stor betydning: Verbalteksten, tekstene uttrykt gjennom bildene, ikonoteksten: sammenhengen mellom de to, og lyden, ettersom bildebøker som regel forutsetter høytlesningssituasjonen. I Frosken er verbalteksten satt opp som et dikt, slik at lyd og rytme i samspill med layout og typografi er viktige modi og deler av budskapet. Boken markedsføres for førskolebarn, og er et eksempel på all-alder-litteratur, i følge min definisjon (Ommundsen 2006, 53).

Frosken har to parallelle historier som etter hvert fletter seg inn i hverandre. Begge historiene tematiserer eksistensielle spørsmål og eksistensiell usikkerhet, angst og frykt. Bildene inneholder mye humor, og balanserer den alvorlige tematikken. Den ene historien handler om en far og en sønn. Faren er blind, og lever i et totalt avhengighetsforhold til sønnen. "Då mor mi levde gjorde ho alt for han", konstaterer gutten. Siden moren døde for fire år siden, har faren plassert sønnen på morens plass. Faren lider av angst og ensomhet. Han kjenner ingen andre enn sønnen, og ber ham stadig love å aldri gå fra ham. Sønnen lover, men inni seg tenker han at han ihverfall skal vente et par dager før han reiser. Sønnens eksistensielle kamp står mellom ansvar og frihet. Han har ufrivillig blitt pålagt ansvaret for faren, og er gått inn i voksenrollen, mens faren har tatt på seg barnets rolle. Det er både en voksengjøring av barndommen og en barnliggjøring av voksendommen. (Ommundsen 2006b, 23, 29-30). 


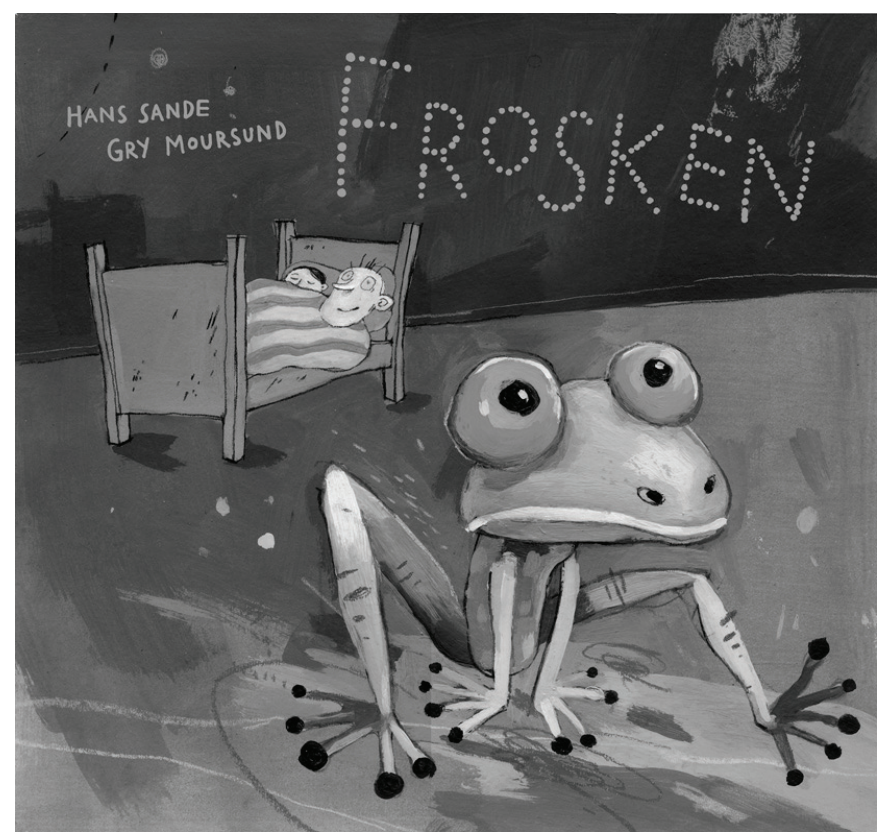

III. I Omslag till Frosken av Hans Sande, text och Gry Moursund, illustration, Oslo: Gyldendal, 2003.

Sønnen lengter vekk, han drømmer om en plass langt borte, om frihet, og om å få vokse opp og ikke lenger bare være sønn. Når faren sier: "Du ser jo. Du ser jo heile verda, alle fargane.", svarer han vemodig: "- Eg ser berre deg". Faren forteller små eventyr eller allegorier. I et av dem sammenlikner han seg selv med en tom, gammel kongle, hvis frø er spredd for alle vinder: "Dei tenkjer berre på å vekse opp til store tre. Ingen bryr seg om meg, ei tom, gammal kongle!"

Den andre historien handler om en undrende frosk, full av eksistensielle spørsmål. I likhet med faren i den første historien sørger frosken over det som er ugjenkallelig forbi. Både frosken og den første historiens jeg-person (sønnen) befinner seg i en overgangsfase i livet, der noe som har vært - barndommen - er forbi. Historien om frosken kan leses som et av farens eventyr:

Det var ein gong ein grøn liten frosk som nettopp hadde vore rumpetroll.

Hit og dit i søledammen hadde han sprella saman med hundrevis av andre rumpetroll.

Men så ein dag var halen borte!

Korleis hadde det gått til? Og korleis skulle han overleve no? (Sande og Moursund 2003, oppslag 2) 
Frosken synes det er vanskelig å forsone seg med tapet av halen, selv når han oppdager at han har fått både armer og bein, og kan svømme mye fortere enn før. Historien om frosken stiller spørsmål om hvordan vi blir den vi blir (hvor ble halen av?), hva vi skal bruke livet til, og hva som skjer etterpå: "Kva skal eg bli etterpå, når eg er ferdig med å vere frosk?" Frosken spør og undrer seg om hvor han skal dra og hva han skal bruke livet sitt til: "Skal eg berre hoppe omkring og seie guk guk?" Svarene han får fra andre dyr, som "Ikkje tenkt på det", er ikke tilfredsstillende. Heller ikke svaret fra de andre småfroskene er tilfredsstillende: "Dei andre småfroskane merka ingen ting. Dei fór til alle kantar. Ingen visste kor dei skulle, men kva så? Det var jo berre å sparke ifrå!"

Bauman hevder at for forbrukerne $i$ et forbrukersamfunn er det å være på farten " - det å lete, å se etter, å ikke finne det, eller rettere sagt ikke å ha funnet det ennå - ikke et ubehag, men et løfte om salighet; kanskje det er selve saligheten. De reiser rundt på en måte som gjør ankomst til en forbannelse" (Bauman 1998, 98). Dette gjelder kanskje for de andre småfroskene, men ikke for frosken i historien vår, noe som kommer særlig tydelig frem i bildene. Han får ikke fred:"- Tankane mine er ein bekk som renn og renn og aldri sluttar, sukka frosken." Men i likhet med Therese i 12 ting som må gjerast rett før verda går under, får frosken sitt Gudsbevis. En dag han svømmer rundt $\mathrm{i}$ bekken og leter etter noen som kan svare på spørsmålet hans, ser han en hvit skygge som vinker til ham i vannet:

- $\AA$, det er ei hand! kvekka frosken.

Ja, det var ei hand med mange fingrar, slik som han sjølv hadde, men mykje mykje større!

- Eg kjem, eg kjem! jubla frosken og sumde beint mot kjempehanda.

/---/

- Eg har sett Guk! jubla den vesle frosken.

- Guk? Kva er det?

spurde dei andre froskane.

- Det er han som styrer og steller med

regnet og bekken og søledammen.

(Sande og Moursund 2003, oppslag 10 og 12)

Frosken ber til "Store Guk" om regn, og dagen etter begynner det å regne. Frosken har fått sitt bevis på Guks eksistens, at Guk hører bønner og kan utrette mirakler. Men for leseren fungerer det som et bevis på at Guk er en illusjon. Bildet på oppslag 10 viser nemlig at det var den blinde faren som satt med hånda nedi bekken og vinket, et 


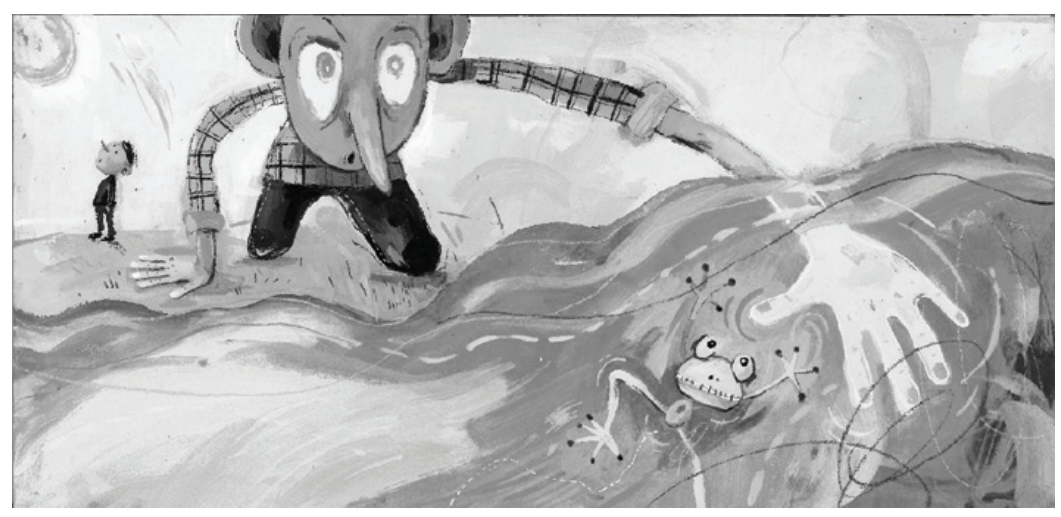

III. 2 Frosken av Hans Sande, text och Gry Moursund, illustration, Oslo: Gyldendal, 2003. sted der de to historiene fletter seg inn i hverandre. (Ill. 2) I følge John Stephens er spesielt paret implisitt leser og implisitt forfatter bærere av sosial praksis og ideologiske posisjoner som "a construction within texts which has little, if any, narrative function, but which operates principally as the bearer of implicit social practices and ideological positions" (Stephens 1992, 21). Oppslag 13 viser frosken i Guks hånd. Men selv om fortellerstemmen i verbalteksten påstår det, og bildet bekrefter kontakten, vet den implisitte leseren at den blinde faren verken kan høre froskens bønner eller få det til å regne. Gud er en illusjon, eller Gud er død, er det implisitte budskapet i Frosken. Frosken vil ikke høre på de andre om hva han skal bruke livet til, og vil heller satse på en instans utenfor og ovenfor seg selv, enn å lete etter svaret i seg selv ut fra de andres fornuftige råd. Nattfiolen hevder meningen med livet er å "stå i ro og lukte godt slik som eg", altså at meningen finnes i nattfiolens egne egenskaper. Ekornet hevder på samme måte at det er å "klive og sprette frå grein til grein". Småfroskene hevder det er å leve livet her og nå, uten å gruble for mye på det. Men frosken finner ikke sin plass, eller hva han skal bruke sine armer og bein til. Han fortsetter livet med å leve på en løgn: Boka slutter med at frosken fremdeles hopper rundt og leter etter store Guk. Men den implisitte leseren, som både må skape forbindelsen mellom de to historiene og fylle ut hullene i teksten (Iser 1978), vet at Guk ikke finnes. Ved å gå inn i rollen som modell-leser (Eco 1989), og pusle brikkene sammen, vil den virkelige leseren forstå at Guk er død. Bare noen måneder etter han stakk hånden i bekken, døde den blinde faren. Henvendt direkte til en tilhører, et du, oppfordrer fortelleren tilhøreren til å opprettholde froskens livsløgn ved selv å ta rollen som Guk: "Men han hoppar fremleis rundt og leitar etter store Guk. Kanskje du vil bøye deg og duppe handa ned i bekken?" 
Også denne boka begynner med slutten. Prologbildet, før selve fortellingen begynner, viser gutten som står og ser på en prikkete vinduskarm. Først etter å ha lest boken kan leseren forstå at det gutten gjør her er å stå og lese blindeskriften faren har prikket inn med syl i karmen. Det han har prikket inn er historien vi leser i boka, historien om frosken. Dette metaperspektivet understøttes av siste oppslag, der ringen sluttes med nok et bilde av gutten ved den hullete vinduskarmen. Nå leser han ikke lenger, for historien er jo ferdig fortalt, og boka er slutt. Etter sin død har faren fortalt sønnen eventyret om frosken, ved hjelp av blindeskriften han har prikket inn. Gutten har fortalt historien til oss. Nå er den ferdig fortalt, og det aller siste bildet er faktisk første gang i boken sønnen smiler. Utenfor vinduet hopper frosken rundt, stadig på leting.

Smilet på siste oppslag gjenspeiler at farens død gir frihet og nye muligheter for sønnen. Først når faren dør kan gutten forlate voksenrollen han var tvunget inn i, bli et barn og voksne opp. $̊$ miste sin siste forelder gir ham dermed bedre fremtidsutsikter og muliggjør en lykkelig slutt. Farens psykiske sykdom, religionskritikken - hvor troen på Gud fremstilles som det å leve på en løgn - og at farens død vurderes som noe positivt for sønnen, er elementer vi kan gjenkjenne fra ungdoms- og voksenlitteraturen. Men i en bildebok for små barn er det temmelig uvanlig. Frosken stiller kanskje de rette spørsmålene, men velger i følge bokas norm feil svar på dem. Hvilket svar han burde ha valgt, må leseren selv tenke ut. Men bokas ideologiske forutsetning er at det ikke finnes en Gudsinstans ovenfor og utenfor Frosken selv. Frosken - og ethvert individ - må finne svaret i seg selv, noe som kan sies å være i tråd med en nyreligiøs forståelse (Kvalvaag 2003, 38).

\section{Fredelig sameksistens?}

Disse to barnebøkene stiller langt på vei de samme eksistensielle spørsmålene, men svarene de antyder er forskjellige. I den ene foreslås en instans utenfor mennesket, nemlig kristendommens Gud, som løsning. I den andre er løsningen å bruke fornuften og finne svaret i seg selv. I følge dialogen mellom Habermas og Ratzinger krever vår globaliserte verden at fornuft og religion må kunne leve sammen i en fredelig sameksistens. I tråd med idéen om den postsekulære tidsalder gjenspeiler 12 ting som må gjerast rett før verda går under det postsekulære samfunnet vi lever i, der religiøse problemstillinger er mer aktuelle enn noen gang. Frosken derimot, kan ved såpass bastant å avvise religionen til fordel for fornuften som svar på eksistensiell 
søking, sies å gjenspeile en gammeldags kulturradikalisme med en religionskritisk og sekularisert virkelighetsforståelse, mer enn den postsekulære tidsalderen den er skrevet i. Samtidig inneholder den også elementer av nyreligiøs forståelse, der enkeltmenneskets liv ikke primært ligger i "Guds hånd", men kan styre sitt eget liv - i stedet for å være styrt av ytre krefter. Mennesket behøver ikke å gå lenger enn til seg selv for å erkjenne tilværelsen, ettersom helheten finnes like mye i hver enkelt som andre steder (Kvalvaag 2003, 38). Ironien i bildet der frosken sitter i Guks hånd, støtter en slik tolkning $i$ en nyreligiøs retning.

Det må understrekes at den postsekulære litteraturen 12 ting som må gjerast rett før verda går under representerer, er noe helt annet enn den didaktiske, religiøse litteraturen fra barnelitteraturens første fase (Ommundsen 2006c). Den post-sekulære barnelitteraturen vekker den slumrende religiøsiteten, den tar troen på alvor, men er verken forkynnende eller moraliserende. Dialogformen kan vi imidlertid kjenne igjen både fra Jostein Gaarders romaner, men også fra den tidlige barnelitteraturen, som i den åpent moraliserende samtaleboka Aftenerne paa Egelund (1852).

Hvem vi er, hvor vi kommer fra og hvorfor vi eksisterer, er eksistensielle allmennmennskelige spørsmål, uavhengig av religiøs tro og bakgrunn. I norsk filosoferende barnelitteratur står en kristen virkelighetsforståelse og menneskesyn sterkt, ledet an av flere av våre beste forfattere. Fraværet av andre religiøse virkelighetsforståelser og gudsbilder er i seg selv interessant. Det finnes overraskende få eksempler på norsk barnelitteratur som reflekterer den flerkulturelle virkeligheten fra innsiden. Etter Khalid Hussains Pakkis (1986), den første romanen skrevet på norsk av en pakistansk innvandrer oppvokst i Norge, har man ventet forgjeves på bølgen av "innvandrerromaner". Det finnes nesten ikke norsk barnelitteratur som reflekterer den flerkulturelle norske virkeligheten fra innsiden. ${ }^{5}$ Globaliseringen vil sannsynligvis etter hvert føre til at også andre religiøse virkelighetsforståelser og gudsbilder i økende grad reflekteres i norsk barnelitteratur. ${ }^{6}$

Samtidig finnes også en filosoferende barnelitteratur som stiller eksistensielle spørsmål, men som antyder helt andre svar. Gudsbeviset og beviset på at Gud er en illusjon, lever side om side i senmodernitetens barnelitteratur. 
${ }^{1}$ Ratzingers innlegg om korrelasjonen mellom fornuft og tro som lim i samfunnet, har siden skapt opptøyer i enkelte muslimske kretser.

${ }^{2}$ Når flere likeverdige stemmer kommer til orde, korresponderer det med Bakhtins begrep polyfoni (flerstemmighet).

${ }^{3}$ Peter Hollindale identifiserer tre typer ideologi i "Ideology and the children's book" (1988), her fra Stephens 1992.

${ }^{4}$ Selv kommer Pullman med en flengende kritikk av CS Lewis Narniabøker som "blatant religious propaganda". (The Guardian 2002)

${ }^{5}$ Det finnes selvfølgelig unntak. Et eksempel er eksilirakeren Walid Al-Kubaisis Sinbads verden (1997), der det er de etnisk norske som blir fremstilt som "de andre", utfra en omvendt "white mythology" (Young 1990). Det sannsynligvis mest kjente eksempelet på kulturmøteproblematikk i nyere, norsk barnelitteratur er Albert Åberg og soldatpappaen (2006), som betegnende nok er svensk. Men det finnes også norske eksempler, som Hege Newth Nouris Hvorfor gråter ikke hunder (2002), der identifikasjonfigurene er to barn med iransk bakgrunn som bor i Norge.

${ }^{6}$ Slik vi ser det i den australske ungdomsromanen Ser hodet mitt stort ut med denne? (2007) av Randa Abdel-Fattah, der hovedpersonens valg om å bruke hijab er styrt av hennes tro og religiøse opplevelse av Guds nærvær, samt at det definerer hennes identitet som muslimsk kvinne.

\section{Bibliografi}

Abdel-Fattah, Randa. Ser hodet mitt stort ut med denne? (Does my head look big in this?). Oslo: Damm \& Søn, 2007 (2006).

Bachtin, Michail. Dostojevskijs poetik. (Problemy poetiki Dostoevskogo). Gråbo: Anthropos, 1991 (1963).

Bauman, Zygmunt. Globaliseringen og dens menneskelige konsekvenser. (Globalization: the human consequences). Oslo: Vidarforlaget A/S, 1998 (1998).

Bergström, Gunilla. Albert Åberg og soldatpappaen. (Alfons och soldatpappan). Oslo: J.W. Cappelens Forlag AS, 2006.

Bibelen. Oslo: Det Norske Bibelselskap, 1978.

Bourdieu, Pierre. "La précarité est aujourd'hui partout". I: Propos pour servir à la résistance contre l'invasion néo-liberale. Paris: Liber-Raisons d'Agir, 1998.

Brenifier, Oscar og Clément Devaux. Hva tenker du om godt og vondt? (Le bien et le mal, c'est quoi?). Oslo: Omnipax, 2005 (2004).

Brenifier, Oscar og Jérôme Ruillier. Hva tenker du om livet? (La vie, c'est quoi?). Oslo: Omnipax, 2005 (2004).

Brenifier, Oscar og Serge Bloch. Hva tenker du om følelser? (Les sentiments, c'est quoi?). Oslo: Omnipax, 2005 (2004). 
Chambers Aidan. Crossing boundaries: the youth novel as the story of creative transgression. Gjesteforelesning ved Universitetet i Oslo 6.4.2006.

Dagbladet: "En dårlig tid". 3.7.2000.

Eco, Umberto. The open work. Cambridge, Massachusetts: Harvard UP. 1989.

Filmweb: "Sofies verden til Hollywood". (Kilde: ANB-NTB 30.4.2007.).

Publisert 2.5.2007 <http:/ / www.filmweb.no/filmnytt/article132912.ece>. (07-08-27)

Habermas, Jürgen og Joseph Ratzinger. Fornuft og religion: sekulariseringens dialektik. (Dialektik der säkularisierung). Højbjerg: Hovedland, 2006.

Hollindale, Peter. "Ideology and the children's book." I: Signal 55: 3-22, 1988.

Huovinen, Milla Elina. “(Anti-) christian ideology in contemporary children's fantasy fiction: Philip Pullman and G.P. Taylor.", 2006. (Ikke publisert)

Hussain, Khalid. Pakkis. Oslo: Tiden Norsk Forlag, 1986.

Iser, Wolfgang. The act of reading: a theory of aesthetic response. Baltimore: John Hopkins UP, 1978.

Kubaisi, Walid al. Sinbads verden. Oslo: Pantagruel Forlag AS, 1997.

Kvalvaag, Robert. Det guddommelige jeg: nyreligiøsitet og religiøse strømninger i moderne ungdomskultur. Bergen: Fagbokforlaget, 2003.

Micaelsen, Vera. På månen spiser de kameler: filosofi for barn. Oslo: Kagge Forlag, 2005.

Nikolajeva , Maria. Children's literature comes of age: toward a new aesthetic. New York: Garland, 1996.

Nouri, Hege Newth. Hvorfor gråter ikke hunder? Oslo: Gyldendal Norsk Forlag AS, 2002.

Ommundsen, Åse Marie. "All-alder-litteratur: litteratur for alle eller ingen?" I: Sverdrup, Kari og Ewo, Jon (red): Kartet og terrenget: linjer og dykk i barne-og ungdomslitteraturen. Oslo: Pax, 2006.

Ommundsen, Åse Marie. “Barndom i senmoderniteten.” I: Årboka 2006. Litteratur for barn og unge. Oslo: Det Norske Samlaget, 2006b.

Ommundsen, Åse Marie. "Barnebokas begynnelse." I: Bache-Wiig, Harald (red). På terskelen: artikler om nordisk barne- og ungdomslitteratur: festskrift til Åsfrid Svensen. 2006. Oslo: Novus forlag, 2006c.

Padley, Jonathan and Padley, Kenneth. "'A heaven of hell, a hell of heaven': His dark materials, inverted theology, and the end of Philip Pullman's authority" I: Children's literature in education 37: 325-334, 2006.

Rhedin, Ulla. "Med ryggen vänd mot förnyelsen" I: Dagens nyheter 6.9.2004. 
Ryan, Mark and Ryan, Carole Hausmann. "Killing God: the propaganda of his dark materials" I: Christian research journal, vol 26, number 3, 2003. Sande, Hans og Gry Moursund. Frosken. Oslo: Gyldendal Norsk Forlag, 2003.

Sortland, Bjørn. 12 ting som må gjerast rett før verda går under. Oslo: Aschehoug, 2001.

Stephens, John. Language and ideology in children's fiction. London/New York: Longman, 1992.

The Guardian: "Narnia books attacked as racist and sexist". Publisert 3.6.2002. <http://www.guardian.co.uk/uk_news/story/0,3604,726739,00. html>. (07-11-27)

Tønnesson, Johan. “Alle tekster er sammensatte". I: Norsklæreren 4/ 2006.

Wall, Barbara. The narrator's voice: the dilemma of children's fiction. Basingstoke: Macmillan, 1991.

Winsnes, Hanna. Aftenerne paa Egelund. Christiania: Wulfsberg, 1852.

Young, Robert. White mythologies: writing history and the west. London: Routledge, 1990.

Årboka 2007: litteratur for barn og unge. Oslo: Det Norske Samlaget, 2007. 